of dreadful objects at once, the multitude, the block, his coffin, the executioner, the instrument of his death, he turned about, and said, 'Home, this is terrible."

\section{If I should die ...}

As regards what dying people feel themselves, all of us should read W N P Barbellion's fournal of a Disappointed Man ${ }^{14}$ and ponder its implications. Could a thanatologist have helped $\mathrm{Mr}$ Barbellion's troubled mind ? I suspect not; but I'm glad there wasn't one around, for the world might have been robbed of a minor literary masterpiece. Here is an example of this young man's writing; he died in 1919, aged 31 , after a long struggle against multiple sclerosis:

"... Yet of a truth it is no use being niggardly over our lives. We are all of us 'shelling out.' And we can afford to be generous, for we shall all-some early, some late-be bankrupt in the end. For my part, I've had a short and boisterous voyage and shan't be sorry to get into port. I give up all my plans, all my hopes, all my loves and enthusiasms without remonstrance. I renounce all-I myself am already really dead."

A vastly different terminal philosophy from that of Barbellion is suggested by the following item from the Los Angeles Times (23 May 1978): "The Ultimate Fan: The man had a heart attack Sunday and was taken to a Seattle hospital. His first request in the coronary care unit was to watch the [basketball] playoff opener between the SuperSonics and the Washington Bullets. Then his heart stopped beating. Doctors worked feverishly to revive him. They succeeded but had to insert a tube in his windpipe. 'He couldn't talk,' Dr Scott Linscott said, 'but he motioned for a piece of paper and a pencil. He wrote that he wanted to know what the Sonics' score was. This from a guy that technically had been dead. Then he pleaded (in another note) for the nurses to let him watch the rest of the Sonics' game on television.' The nurses were hesitant but finally let him watch the Sonics win, 106-102. The man, whose name wasn't given, was reported to be resting comfortably Monday."

If I have a terminal philosophy myself it is that all of us are, or at any rate should be, thanatologists. I'm not just talking about the medical and allied professions-I'm talking about everyone. We're all in this together-in the words of that old chestnut, none of us are getting out of this world alive-so why aren't we more supportive of one another during life? In Saul Bellow's novel Herzog, Herzog observed that "life was life only when it was understood clearly as dying." And, of course, more than three centuries ago John Donne said it all so wonderfully: "No man is an island, entire of itself; every man is a piece of the Continent, a part of the main. ... Any man's death diminishes me, because I am involved in mankind; and therefore never send to know for whom the bell tolls; it tolls for thee."”15

But let me end on a more cheerful note by recalling that the novelist John Updike once observed "we do survive every moment, after all, except the last one."16 And concerning that last moment-or, rather, those last moments-let each of us strive professionally and personally to ensure that each dying person we encounter could say (as indeed did William Hunter, the great Scottish anatomist and obstetrician) at the end that "if I had strength enough to hold a pen, I would write how easy and pleasant a thing it is to die."

Part of this paper was presented at a seminar on Psychosocial Care of the Dying Patient held at the School of Medicine, University of California, San Francisco, 2-3 June, 1978.

\section{References}

${ }^{1}$ Finch, J S, Sir Thomas Browne, p 266. New York, Henry Schuman, 1950

2 The Works of Sir Thomas Browne, vol 1, p 166, ed G Keynes. London, Faber and Gwyer, 1928.

${ }^{3}$ UCLA Daily Bruin, Los Angeles, 25 April 1978, p 12.

4 Los Angeles Times, 18 May 1978, p 13.

${ }^{5}$ Barna, Yon, Eisenstein, p 172. Boston, Little, Brown, 1975.

${ }^{6}$ Zimmerman, L M, and Veith, I, Great Ideas in the History of Surgery, p 144. Baltimore, Williams and Wilkins, 1961.

${ }^{7}$ Jung, C G, Memories, Dreams, Reflections, p 116. London, Collins (Fontana), 1971.

${ }^{8}$ The Oxford Book of English Prose, p 45, ed Sir Arthur Quiller-Couch. Oxford, Clarendon Press, 1966.

${ }^{9}$ Brown, P Hume, $A$ Short History of Scotland, p 96. Edinburgh, Oliver and Boyd, 1955.

10 Rorem, Ned, The Final Diary, p 26. New York, Holt, Rinehart, and Winston, 1974.

${ }^{11}$ Aubrey, John, Aubrey's Brief Lives, p 96. Ann Arbor, University of Michigan, 1962.

${ }^{12}$ Rorem, Ned, The Final Diary, p 164. New York, Holt, Rinehart, and Winston. 1974.

${ }^{13}$ A Century of Humourous Verse 1850-1950, ed Roger Lancelyn Green, p 117. London, Dent, 1968.

${ }^{14}$ Barbellion, W N P, The fournal of a Disappointed Man, p 85. London, Chatto and Windus, 1919.

${ }^{15}$ The Complete Poetry and Selected Prose of Fohn Donne, p 332. New York, Modern Library, 1941.

16 Updike, J, Picked-up Pieces, p 498. Greenwich, Connecticut, Fawcett Crest, undated.

\section{A shush of librarians}

\author{
GILLIAN M PENTELOW
}

"Can you find the first description of Hodgkin's disease before
tomorrow ?" "I would like to have a colour transparency of a
picture in Zerbi's monograph on old age printed in 1489; there
is a copy in the Vatican Library." "I want to quote 'Forty
years on' at Dr Jones's retiring party but I must get the words
right." "Some of our physiotherapy students will soon be
starting their finals project, would you show them how to
find appropriate references ?" "I am working out a new research
project, would you find out what has been written in the last
five years on adverse effects of monoamine oxidase inhibitors?"
These are typical queries encountered by a medical librarian-
a shush of librarians, indeed.
For many years large institutions such as teaching hospitals,
industrial firms, and universities have had their own libraries.
Small hospitals have had haphazard collections of books and
journals-some bought, and some given by generous members of staff. These "libraries" were usually looked after by busy secretaries, some of whom became efficient secretary/librarians; others were run, sometimes all too literally, on self-help. Medical staff who needed a more comprehensive library service relied on membership of the British Medical Association, Royal Society of Medicine, royal colleges, local medical societies with insufficient funds, such commercial libraries as $\mathrm{H} \mathrm{K}$ Lewis's, or sought help from their teaching-hospital libraries. The staff of all these provided excellent services-as they still do-but the efforts required by the user and the fact that the answers to queries could not always be given immediately deterred all but the most enthusiastic.

Several factors combined to change this state of affairs. About 15 years ago some doctors realised that libraries were needed to supplement the district general hospitals' educational function. In the late 1960s the Todd ${ }^{1}$ and Bonham-Carter ${ }^{2}$ 
reports recommended that doctors and all Health Service personnel should have access to "adequate library services." Recognition by the royal colleges that posts are suitable for candidates taking postgraduate examinations depends, in part, on the availability of a library service. The Council for Postgraduate Medical Education and the British Postgraduate Medical Federation supported the establishment of a network of regional libraries, and, as a result, five health regions now have co-ordinated library systems; five have a formal contract with a medical school or other medical institution to provide "back up" services; and most of the others have local cooperative arrangements. Today, over 700 staff-most of whom are qualified librarians-are providing a service for employees of the National Health Service.

\section{How a medical librarian can help}

What can be expected of a medical librarian? The Library Association's Guidelines ${ }^{3}$ recommend that an effective district library should provide a wide range of stock and services. The stock should include textbooks, monographs, reference works, government reports, official pamphlets, audiovisual material, journals, indexes, abstracts, and bibliographies. To ensure that readers can make full use of the potential of the library resources the librarian should: maintain and organise the collection; co-ordinate the purchase and maintenance of bench books for use in wards and departments; provide reference and interlibrary loan services and photocopying and translation facilities; and prepare bibliographies and disseminate current information.

Smaller libraries cannot and should not aim at supplying the whole range of stock and services. All librarians have to decide whether to buy extra copies of textbooks at the expense of standard monographs needed by specialists; whether to bind journals or spend the money on extra titles; and whether it is more economical to provide, for example, computerised information retrieval in the library or to share a terminal with a nearby university. We know that it would be as pointless for a library in a postgraduate centre to try to imitate that of a medical school as to expect the Royal College of Obstetricians and Gynaecologists to provide a comprehensive collection on orthopaedics. A doctor working with one specialised organisation may require information found in another; a patient with a rare disease may be admitted to a small local hospital which has a library with insufficient specialised material to cope with the urgent demands of the medical team. The librarian on site will know how to exploit his stock and then enlist the help of a wider network of regional and national libraries.

Although medicine has always been a well-documented subject, compiling a list of references used to be a lengthy process that included a painstaking search through the bibliographies. Some library users compiled their own lists, but others gave the librarian a subject-not always very precise -and awaited results. Searching by "hand and eye" is still the best method of finding recent publications by a specified author or references to articles on the treatment of a specific disease, and it is the only way of tracing older material. It is inadequate, however, for finding references on complicated many-faceted subjects.

The rapid development of computerised information retrieval now available through the regional networks has enabled us to cope with the "information explosion." BLAISE-not, on this occasion, the patron saint of sore throats, but the British Library Automated Information Service-has made available several data bases. Those most useful to the medical profession are Medline (for medicine), Toxline (for toxicology), and Cancerline (Cancerlit for published material; Cancerproj listing research projects in progress; and Cancerprot dealing with the clinical aspects of new anticancer agents and treatments). The most successful searches result from the inquirer (with the technical knowledge of his subject) working at the terminal with the librarian who knows the coverage and characteristics of the data bases. It is possible to change from one data base to another during the search, and lists of references can be updated at regular intervals. Searches may be prepared and sent by post to the BLAISE office, where the staff will process them on behalf of users who have no access to a terminal. A search using Medline will print instantly references to articles indexed in Index Medicus in the last two years; older articles will be listed offline and received by post. Abstracts of up to 200 words can be printed online and, although this adds to the cost because more computer time is used, it is not too expensive when set against the inconvenience of borrowing a journal from another library and discovering that it does not mention the detail that is needed. The cost of computer time is $£ 25$ an hour, but we find that most online searches take under 15 minutes.

In the past, a major source of irritation was tracing obscure references, but now that the scope of bibliographies has been extended the task is easier. Index Medicus originally indexed journal articles under authors and subjects, but since January 1976 it has included in its monthly issues and annual cumulations analytical indexing of the contents of multiauthor monographs and conference and symposium proceedings. In 1973 Current Contents: Life Sciences and Current Contents: Clinical Practice added the contents lists of multiauthor works to their existing coverage of a wide range of journals.

The bibliographies have been complemented by a currentawareness service. The librarian scans journals, publishers' blurbs, and material received in the library and alerts readers to new publications relevant to their work. Some librarians keep files on their users' interests, but in smaller libraries it is possible to tell readers in a less formal way. There are now several published current-awareness services designed to meet general and specialised requirements. Humberside Area Health Authority, for example, issues free monthly lists of annotated references from its information and reference service on care of the child, care of the elderly, care of the mentally retarded, and health care administration. The staff of the Oncology Information Service at Leeds University medical library produce monthly bulletins on 15 clinical subjects such as pain, cancer chemotherapy, and skin cancer. The Medical Audio-visual Aids Information Service at Dundee University supplies "study packages" made up of lists of annotated references to journal articles, selected books, and audiovisual programmes. These cover 15 topics including cardiac arrest, neonatal jaundice, and abdominal pain in general practice.

\section{Additional services}

The availability of all these aids has stimulated the use of the inter-library loan service. A recent survey by the London University Library Resources Co-ordinating Committee's standing advisory panel on inter-library loans showed that most of the librarians in the university apply first to the British Library Lending Division for material that they do not stock. Situated at Boston Spa, Yorkshire, this library supplies books, photocopies of journal articles, and microform copies of theses. Material available at Boston Spa is supplied quickly and requests for other items are passed to the "back up" libraries, which include the Royal Society of Medicine and, if necessary, any foreign library. If none of these can supply the item, the request is returned and the librarian then becomes a Sherlock Holmes.

We enlist the help of medical libraries as well as those which deal with subjects outside the boundaries of medicine. For instance, we have recently borrowed reports from the British Cast Iron Research Association Library and received information from the Glass Manufacturers' Federation. Audiovisual material may be borrowed from Graves Audio-visual Medical Library and some pharmaceutical companies. Library bulletins are useful when trying to trace elusive material. The Department of Health and Social Services, the Office of Population Censuses and Surveys, the Scottish Health Service, and the South-east Thames Health Care Planning Library issue subject lists of 
recent acquisitions. Some also include titles of bibliographies which they have prepared, lists of forthcoming meetings and conferences, and new journal titles held by the library.

As technology advances readers expect easier access to the ever-growing mass of published information in book, journal, or report form irrespective of whether it appears in print or in machine-readable form. With this in mind, the British Library is sponsoring a clinical librarianship project at Guy's Hospital Medical School. In this scheme the clinical librarian is a member of the library staff but is also part of the multidisciplinary medical team. He or she attends case conferences, ward rounds, and team meetings and supplies "literature" searches and information to the members of the team. The service is based on the library, and information files are built up for future use. Although the scheme is working well in some centres in the United States, there has been considerable discussion about its application (and, indeed, relevance) in Britain. We await the outcome of the Guy's experiment with great interest.

Some readers assume that our medical and technical knowledge equals theirs. There are universities where librarianship degree courses are combined with subject specialisation -human biology, for example-but we should like the users of our libraries to remember that many of us have acquired our medical knowledge by osmosis. Our exacting role was well described by P J Bishop: "Librarians are in a special position because ... they are able to act as a bridge between the literature and the reader." 4 Through our knowledge of the tools of our trade-bibliographies, reference works, subject coverage of journals, scope of monographs and textbooks, computer data bases, and the resources of other libraries to say nothing of the "old boy network"- - we can complement the technical knowledge and professional skills of the contemporary doctor.

\section{References}

${ }^{1}$ Royal Commission on Medical Education, 1965-8 Report, Cmnd 3569. London, HMSO, 1968.

2 Committee on the Functions of the District General Hospital, The Functions of the District General Hospital, London, HMSO, 1969.

3 Library Association, Guidelines for Library Provision in the Health Service: a consultative document, London, Library Association, 1978.

${ }^{4}$ Bishop, P J, British Medical fournal, 1979, 1, 551.

\section{Suggested further reading}

Morton, L T, How to use a medical library, 6th edn. London, Heinemann, 1979.

Picken, F M, Teach-In, 1974, 3, 203, 237, 297, 427, 506.

Picken, F M, Hospital Update, 1975, 1, 59, 563.

\section{The wound and the vision}

\section{T D V SWINSCOW}

The nineteenth century was the golden age for naturalists. Heroic individuals, daring expeditions, and lively local societies composed largely of amateurs joined in an exhilarating pursuit of wild life. And not only life, for they were after minerals, palaeolithic axes, shells, fossils-everything in the natural world. Bankers vied with industrialists to finance expeditions to remote places in the hope of having their names commemorated in the new species to be discovered there. Finally, after the orchids, the beetles, and the dinosaurs, another object came under the same kind of scrutiny-man himself in all his perplexing variety. At this point the bakers drifted away, and even medical men became apprehensive. When a bookseller was prosecuted in 1898 for offering an obscene book for salenamely, Sexual Inversion by Havelock Ellis-no doctor would risk his reputation for it on the committee of defence or as a witness in court.

\section{Art and science precariously balanced}

Though half of Havelock Ellis's life fell in the twentieth century, it is as one of the great naturalists more typical of the nineteenth that he stands out today. His Studies in the Psychology of Sex in six volumes, with a later supplementary volume, were unequalled in their day as sources of information on sexual and erotic behaviour in many nations and cultures, and the work remains unsurpassed in its wealth of detail, the immediacy of the case histories personally recorded, and the elegance and fitness of the language with which he expressed commonplace as well as exotic findings. Art and science were precariously balanced in Havelock Ellis, and both animated his writings. In the course of his long life he published on a great variety of

Havelock Ellis: Philosopher of Sex. A Biography. Vincent Brome. (Pp 271; £8.95.) Routledge and Kegan Paul. 1979. subjects outside sexual behaviour, among them criminology, drama, dance, a national health service (in 1892), and the nature of genius, as well as poetry and literary criticism. But it was his studies of sex, as candid as they were copious, that changed the thought of his time and so of ours.

It is therefore natural to ask what sort of man he was, and it need not be thought intrusive to inquire into the sexual feelings and behaviour of one who regarded the study of them as his life's main work. Ellis's own account of his life, published in 1940 , is a deeply moving book despite its meeting the same fate as many of his others-condemnation from the reviewers, who expected something different. Several relatively limited biographies have appeared over the years, and now Mr Vincent Brome has provided a fuller account, for he has had access to much unpublished material and has conversed or corresponded with people of importance in Ellis's life. Even so, a complete biography setting the subject in a psychological and historical context has yet to be written.

Born in 1859, Havelock Ellis had what he himself considered a happy childhood, though owing to the frequent absence of his father, a sea captain, Havelock's mother and four younger sisters composed a predominantly female household. A voyage round the world at the age of 7 with his father was an unusual experience. An undistinguished career at school followed, and then at 16 Ellis sailed again with his father, this time to Australia. By pure chance, and without any particular qualifications, he remained in Australia as a school teacher when his father's ship sailed on, and it was there that he had one of the most extraordinary experiences that can befall anyone. Intensely lonely in the outback, deficient in formal education, disturbed by adolescent daydreams, he was suddenly transported at the age of 19 by a kind of mystical rapture, a sense of exaltation, and a revelation of harmony between "the divine vision of life and beauty which for me had been associated with a religion I had lost" and "the scientific conception of an evolutionary world." These words of his epitomise much of his life's work. 